\title{
Major Sources Of Challenges Facing The CPA Profession And Suggested Recommendations
}

Morsheda Hassan, (E-mail: morshedat@yahoo.com), Grambling State University

Michael Luehlfing, (E-mail: luehlfing@cab.Latech.edu), Louisiana Tech University

Macil Wilkie, (E-mail: wilkie@alpha0.gram.edu), Grambling State University

\begin{abstract}
This paper explores major sources of current changes facing the CPA profession today and tomorrow. This paper also discusses major sources of challenges facing traditional CPA services and new assurances services. In addition, the paper offers recommendations that will enhance the competitiveness of the CPA profession in future markets.
\end{abstract}

\section{Introduction}<smiles>c1ccccc1</smiles>
auser (2000) suggests that while the relevance of accounting to business is not changing, the responsibilities and career options of accountants are expanding. Although traditional services provided by CPAs (accounting, auditing, tax preparation, and consultation) continue, new roles for some of them are taking place. Pethley and Fremgen (1999) claim that the accounting profession is facing drastic changes. The marketplace, clients and professional expectations are suddenly different. Clients expect many more services as they continuously reevaluate their processes and products in order to deal with worldwide competition. Clients also expect that their CPAs would warn them in advance about the influence of accounting changes on their financial reporting and to advise them about systems changes required to satisfy new marketplace demands. The profession is struggling with what services to offer and spending a great deal of efforts to reposition itself to face often confusing marketplace demands. Reeb (1999) confirms that change is inevitable, driven by market. CPAs are being called on to address the potential changes. If CPAs don't respond to the needs of their clients, they will go elsewhere. CPAs hold their future in their hands; they have to decide how to position their firms the marketplace of tomorrow.

In sum, the present and future marketplace presents new client needs, changing client expectations, and new forms of competition that will have substantial effects on CPA services provided and revenues generated. Hence, how CPAs will compete effectively in such future markets? This study answers this question.

\section{Competitive Environment}

The special committee on assurance services (SCAS) established by the American Institute of Certified Public Accounts (AICPA) has identified two relevant competitive environments that are evolving independently. These two environments involve traditional CPA services and new assurance services. Accounting firms might encounter different challenges in competing for traditional CPA services and new assurance services.

\section{Major Sources Driving Competition in Traditional CPA Services}

The market for traditional CPA accounting and auditing (A\&A) services is expected to become more competitive. AICPA (1997) refers to the following sources driving competition in traditional CPA services:

Readers with comments or questions please contact the author via email. 


\subsection{Non-CPA}

Where services are not reserved by regulations for CPAs, other providers will enter the market. These competitors enter the market to establish distribution channels for their primary businesses, such as selling investments or other services. Financial planning and retirement planning are two examples of financial services provided by nonCPAs.

\subsection{Price competition among A\&A firms}

Price competition among A\& A is expected to continue and to hold down revenues. As it appears in the chart below, revenues of A \& A firms have been flat for the past several years when adjusted for inflation. The chart in Figure 1 shows the revenue for the period between 1989 and 1995 has been flat. The data have been collected for sixty largest firms in the United States.

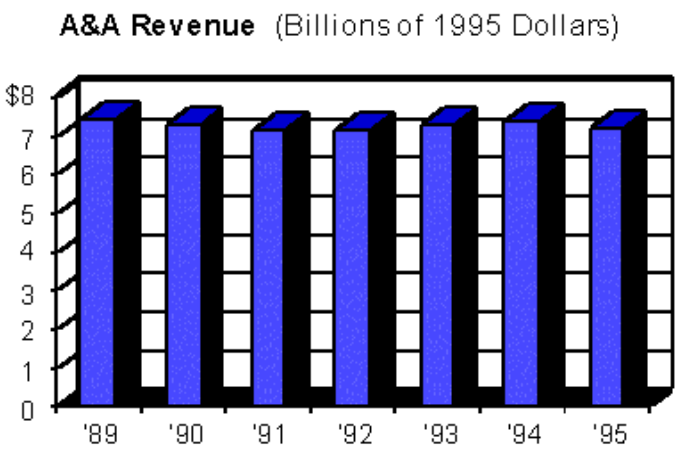

Source: Lane D. Sauser. The CPA Profession: Responding to a Changing Environment. SAM Advancement Journal. (Spring, 2000).

\subsection{Increasing client sophistication}

Sophisticated clients may acquire their own CPA talent or other financial specialists who develop internal information. These skillful financial managers are able to perform the data summarization and analysis used to be provided by CPAs as additional services.

\subsection{Technology substitution}

Software will continue to improve and will compete effectively with CPAs, enabling clients to "do it you yourself" on low-end services. Examples include tax preparation software and bookkeeping software that is userfriendly and coaches the non-CPA through financial statement preparation.

\subsection{Decreased demand by users}

The traditional output of accounting and auditing and tax work has lost market share in its place. The results of the survey of decision makers conducted by AICPA (1997) indicates that other sources of information are available on which to base decisions. The chart below graphically represents the effect of information sources other than financial statements. For example, lenders are making loan decisions based on computerized credit scoring techniques rather than insisting on audited financial statements.

\section{Major Forces Driving Competition in New Assurance Services}

What CPAs today and tomorrow must face is that new services will be market-driven. Demand for new services will not be created by new laws or regulations. Moreover, the provision of these new services will not be limited to licensed CPAs. CPAs will have to provide value and compete in a new environment with a range of nonregulated potential information providers, resulting in a changed competitive battleground. The special committee on AICPA (1997) refers to the following new competitors: 
Figure 2

Information Sources

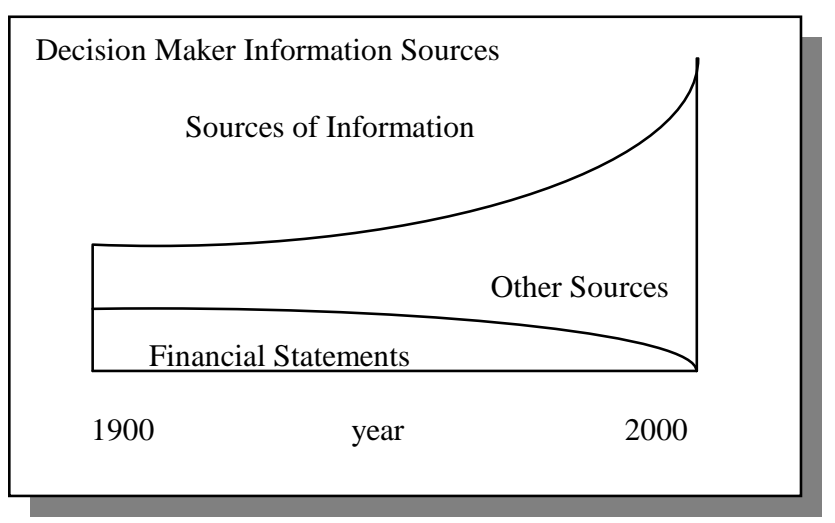

Source: Lane D. Sauser. The CPA Profession: Responding to a Changing Environment. SAM Advancement Journal. (Spring, 2000).

- Highly capitalized large competitors - - Large competitors may be able to raise debt or equity capital to finance leading edge technology, advertising, or the creation of large service networks

- Unconstrained by CPA rules - - Many states regulate everything that a CPA does, so that CPAs are regulated in ways non-CPAs are not. A CPA firm may be constrained in the types of business it can accept, the fees that can be charged, and the kinds of reports that can be issued.

- $\quad$ Nimble - - CPAs have traditionally been deliberate and focused on standards that evolve over time. New competitors will be more proactive to exploit new opportunities. These new competitors will be willing to take more risks.

- $\quad$ Subject matter experts - - CPAs have the opportunity to build assurance skills on their knowledge of accounting, auditing, and tax. Competitors may well possess the content knowledge that may be highly valued by customers.

- Information providers - - Competition to provide information will come from those who have access to public or propriety databases. Competition also might come from computer systems, and (6) Certified in other disciplines - - Some organizations provide certifications that sound like CPA while they are not. Some of them might try to build barriers to exclude CPAs from providing new services.

\section{Enhancing The Competitivene Of The CPA In Future Markets}

Pethley and Fremgen (1999) assert that the accounting profession is facing drastic changes. Clients have different and various needs and demands. While the profession is confused about what service to seize, it is working hard to face the challenges of new market demands. Seigel, Kulesza and Sorensen (1997) have already asked, how well prepared are accountants in business and industry for the new accounting? How well prepared are financial managers in public practice for their changing relationships with corporate clients? Hunger and Wheelen (2000) contend that in order to stay in business, a firm must be prepared to compete effectively and must understand the environment. Therefore, firms of every size need to examine their place in the market for traditional CPA services and new assurance services.

With changes expected in the environment, CPAs should take steps to be ready to meet the challenge. With the aforementioned sources of competition, how can the CPA stay competitive in the market? The following recommendations are provided: 


\subsection{CPAs should be ready for the new accounting era}

The results of Seigel and Kulesza and Sorensen's (1997) study discover that the role of accountants in business and industry is changing. To prepare for the new accounting (where the emphasis is on information analysis and strategy setting rather than on the conventional tasks of data collecting and historical reporting), the authors propose the following:

- Industry accountants - - CPAs who work for profit and nonprofit organizations, education, and government) should arm themselves with the skills they will need if they want to succeed as true business partners, to prepare their finance operations more effectively and to develop aids in performance evaluation, recruiting and training, and career counseling.

- $\quad$ Public accountants - (Those who work in CPA firms) should develop new services.

- $\quad$ Accounting educators - should develop new curricula that will better prepare students for work in corporate accounting.

Likewise, Zarowin (1997) recommends the following: (1) CPAs should develop facilitation skills that enable them to excel as change agents, (2) CPAs should think of themselves not so much as accountants (bookkeepers), but as knowledge professionals, (3) CPAs should get used to not just looking back at historical data, and (4) CPAs should recognize that it takes great courage to give up what they are doing well now for something they know will replace it in the future.

\subsection{A new definition is required for the CPA profession}

Pethley and Fremgen (1999) believe that the concept of "accounting" or "accountancy" no longer properly describes a profession moving to higher levels of information management. They propose that the profession redefines itself as being concerned with acquisition, analysis, reporting and use of information (financial and nonfinancial, internal and external) required to effectively operate, manage and assess an organization and its numerous activities.

The above authors look for a definition based on the broad concept of information, better describes the present activities of the profession, and provides breadth required for the future growth of this profession. Therefore, they propose that the new profession name should be "information consultancy" to provide the proper opportunity for specialization (audit, tax, computer systems, industry, management reporting). This definition best identifies the current CPA profession and its capacity for future.

According to these authors, the body of knowledge that would qualify a person as an "information consultant" should involve management techniques, computers, computerized information systems, and the various functions demanded by an organization to implement its mission, including accounting. This definition would describe several roles of the profession in managing the whole organizational information rather than abstracted parts of it. Finally, this definition would recognize the realities of the CPA practices today.

\subsection{Establish professional requirements for information consultancy}

Pethley and Fremgen (1999) believe that there is a need for establishing the CPA professional requirements and qualifications for information consultancy to meet the needs of clients in defining, developing and using information in a high-tech global environment. Although many CPAs today can assist clients with these needs, some lack recognized, well-established professional qualifications. Accounting is a long and well-established informationoriented profession, well suited to fill the role of information consultancy under the protection of the designation "Certified Information Consultancy". 
The authors notice that as computers bring us more information faster, it has become clear that an "accounting system" is in some ways an abstraction and that almost all of an organization's information eventually has financial significance. This new, integrated information universe makes possible for management, auditors and consultants to better understand an organization's activities and how they affect its well being. As the information revolution continues to gain speed and the accounting profession's involvement in it becomes more challenging, the direction that the profession to take is understanding information.

\subsection{CPAs must change their current strategic vision.}

According to Tichy and Charan (1989), strategic vision is a description of what the firm is capable of becoming. It is often communicated in the mission statement of the firm. Carlozzi (1998a) suggests that CPAs must change the elements of their vision to meet the new challenges facing their profession. The CPA vision process is a nationwide initiative intended to gather input from CPAs in all segments of practice to create a unified and comprehensive vision of the profession's future. In her article "Map the road ahead", Carlozzi reports that a coalition including representatives of the American Institute of CPAs and state CPA societies has created a CPA vision process that will help the CPA profession:

- $\quad$ Keep up with the marketplace's changing demands.

- $\quad$ Identify and prepare for future opportunities and demands.

- $\quad$ Redefine and leverage core competencies and values of the profession.

- $\quad$ Draw together to create a vibrant and viable future.

In her another article, Learning for the Future, Carlozzi (1998b) insists that CPE must change to meet the new challenges facing the profession. She reports four categories (values, services, competencies, and issues) for the vision, where each category includes five elements. She summarizes them as follows:

- National top-five values are: Continuing education and lifelong learning, competence, integrity; attunement with broad business issues, and objectivity.

- National top-five services are: Assurance, technology, management consulting, financial planning, and international.

- National top-five competencies are: Communications skills, strategic and critical thinking skills, focus on client and market, interpretation of covering information, and technological adeptness.

- $\quad$ National top-five issues are: (1) the future success of the profession depends on public perceptions of CPA abilities and roles, (2) CPAs must become market driven and not dependent on regulations to keep them in business, (3) the market demands less auditing and accounting and more value-adding consulting services, (4) specialization is critical for the future survival of the CPA profession, and (5) the marketplace demands that CPAs be conversant in global business practices and strategies.

\subsection{The CPA brand should differentiate CPAs from the competition}

Elliot (2000) sees CPAs of the future as the people who help individuals and organizations through the strategic use of information systems. His message indicates that the profession needs to reinvigorate its services offerings. CPAs cannot ignore the long-term risks the profession faces. Therefore, he proposes that CPAS must take the following imperative steps: (1) CPAs must continue to develop new services, (2) CPAs must reform pre-entry and continuing education to prepare members to take advantage of the opportunities in the marketplace, (3) CPAs must create a Web-based Institute, one that becomes a knowledge hub for the profession, (4) CPAs must market in order to increase demand for the profession's services and to make the profession consistently preferred to its competitors, and (5) CPAs must strengthen feedback loops from the marketplace to assure that we continually adapt service offerings and quality to client and employer's needs. 


\subsection{CPAs must communicate effectively with their clients}

Although Golen (1998) realizes that most CPAs understand the importance of effective communication with clients, he advises SPAs to periodically take a step back and evaluate the communication skills they use to get their message across. To maintain open communication with their clients, Golen suggests these tactics:

- $\quad$ Convey an attitude of trust - - Improving the level of trust between two people helps to open communication lines. Once trust has been established, ideas flow more effectively.

- $\quad$ Listen carefully - - Everyone likes to be heard, especially clients. Try to listen more emphatically; try to listen twice as much as you speak.

- $\quad$ Stay calm - - Even if a client becomes angry, maintain your patience. Staying calm is critical to fostering a climate that enhances communication, particularly when the client is emotional. If you and your client both get excited, nobody wins.

- $\quad$ Accept personality differences - - If you have a situation where personality clashes may adversely affect communication, accept it as something you cannot change. Try to see the situation from the client's point of view, and avoid showing frustration.

- Organize your ideas - - When conveying information to a client, particularly with respect to complex issues, it is important to convey your message in an orderly manner. Present the information in a way that is logical and meaningful to the client.

- $\quad$ Adopt a positive attitude - - If a client says something that puts you on the defensive, don't overreact and make excuses. Instead, provide sound reasons for the actions you took.

- $\quad$ Avoid either/or thinking - - All issues are not black or white. Accept the fact that there may be shades of gray. Don't polarize your thinking. Keep your mind open to new interpretations.

- $\quad$ Provide feedback - - Nothing can be more frustrating to a client than not being kept informed. Even if you have nothing concrete to report, clients should have an opportunity to ask questions. Let your clients know that they haven't been forgotten.

- $\quad$ Avoid information overload- - Don't give the client too much information at once. If you are discussing a complex issue, break the information into easily understood chunks. If a client feels overwhelmed, everything you say after that point is meaningless.

- $\quad$ Avoid using jargon - - Always remember whom you are talking to. If you have to use a term the client is not familiar with, be sure to define it in understood words.

\subsection{CPA firms Should Build on the strengths of their firms}

Elliot and Pallais (1997b) advise CPA firms to choose what their firms can handle from the available opportunities concerning assurance services. Each firm should consider its own characteristics, resources, specialties, and the potential fees from and costs of offering a new assurance service. Elliot and Pallais suggests the following approaches:

- Matchmaking - - When the firm decides to offer an assurance service, this service should fit the firm's reputation and culture. The more closely the competencies required for a new service match the firm's strengths, the better the fit. A good fit offers a firm a competitive advantage over competitors. The competitive advantage of a good fit also can come from being able to sell the service at lower cost to provide a better service at a competitive price. However, a misfit does not only reduce the probability of success in the choice of the assurance service but it negatively affects the current successful operations of the firm.

- $\quad$ Estimating costs and return - - To determine potential revenues, the firm must multiply the anticipated fee per service by the estimated number of customers. To estimate a fee, the firm should start with a fee that clients will accept. Estimate might be made by using the fees for comparable services and refining that figure with formal or informal market research. When fees for comparable services are very tough to depend on, make a direct estimate of the value to the customer. 
To estimate the number of the customers, use the following three figures: (a) the total possible number of customers for these service in the marketplace, (b) the percentage of those who are likely to actually buy the service, (c) the percentage of the buyers that the firm can expect to get from the marker share.

- $\quad$ Competency gap analysis - - New services may require new competencies. This issue depends on whether the firm already has the required competencies. However, no potential services can be decided until the firm evaluates its ability to provide them at a professional level. If there is a gap between the existing competencies and the required competencies for new services, the firm can close the gap by training, hiring, or reducing service offerings.

- $\quad$ Liability risk - - New services carry liability risks. CPAs should first determine whether the risks are acceptable to the practice or would add too heavy burden. If risks are acceptable, they can be controlled by the way the CPA structures and delivers the service.

Possible techniques that reduce litigation risk for existing services can be integrated into the process of developing new assurance services as follows: Cautionary language can help protect assurers from unwarranted liability when used in information describing an assurance engagement and in assurance reports; Structuring new assurance services to be governed by contract law, not tort law, promises advantages in many circumstances; Loss-limiting clauses should be considered when arriving at engagement terms. These are contractual clauses that agree to identify the client a specified amount for losses caused by the services delivered, or agree that the client will indemnify the account for claims by third party, (d) alternative dispute resolution can be required by an engagement letter or can be agreed to after dispute arises.

- $\quad$ Conflict of interest - - When deciding whether to develop or provide a new assurance service, the firm should consider potential conflict of interest. Independence presents a problem that could grow as new assurance services play a larger role in the practices of CPAs. This problem is how to make judgements without authoritative guidance for the endless variations of new assurance services that are possible. Clearly, firms need a concept of assurance independence to apply to new services.

- $\quad$ Good judgment - - Good judgment is a key for screening potential services and gearing up to provide new assurance services. There are few certainties in estimating costs and benefits in determining potential market share, in establishing competency needs, and in assessing litigation risk. Judgments should include potential revenues, necessary investments, acquiring the necessary competencies, the consistency of service the desired image and reputation, reasonable litigation risks, and any potential conflicts of interest?

\subsection{Integrative plan by four major groups within the profession}

Sinclair (1993) proposes that competency issues may be addressed by four major groups within the profession. These groups include higher education (universities, colleges, faculty, and students), AICPA and state societies, CPA firms, and individual practitioners. AICPA (1997) describes possible actions by each group.

- Higher education - - Initiatives of the Accounting Education Change Commission (AECC) are beginning to spread through higher education. This diffusion is moving the curriculum for accounting majors in a direction consistent with the recommendations of this committee. With this context, universities and colleges need to respond by adapting curricula to prepare accounting majors for positions in industry and public accounting that differ from present responsibilities.

Emphasis should be geared toward gaining a better understanding of user needs, identifying information relevant to the user decision process, and gaining better understanding of how information technology is transforming all aspects of business. Audit education also needs to emphasize customer focus that provides reliability and relevance to decision making. The challenge for higher education is to continue providing the required skills for CPAs in the future.

- $\quad$ AICPA and state societies - - Continuing professional education courses (CPE) and workshops offered by 
AICPA and other membership organizations will make a major contribution to improving competencies of the profession. Currently, all CPAs must complete 40 hours of CPE each year to retain their current certification. This notion represents a strong mechanism in which new competencies can be added. However, priority should be given to help practitioners in small firms because they lack the resources required to develop instructional materials for all of the new assurance services that small firms may offer. The CPA exam should focus on materials fit future developments.

- $\quad$ CPA firms - - The contributions that might be offered by CPA firms will depend on their size, the extent to which they have in-hose capabilities for instructional development and delivery, and the extent to which they choose to hire professionals with designated competencies rather than building those competencies internally. Small CPA firms will seek the help of AICPA and state societies for CPE courses to build competencies in potential assurance services. Large firms will focus on new assurance services that are profitable. These firms can choose either to hire professionals or develop appropriate in-house training to support their targets.

- Individuals - - A great deal of major competencies required for CPAs comes from CPE courses and CPA firm training programs. On the job training will also contribute significantly to the development of competencies described before. However, CPAs must realize that their commitment is a determinant factor in enhancing their competitive competencies. For example, enhanced competencies in information technology will only occur by the willingness of the individuals who keep abreast of developments in information technology. Another critical factor is the individual's personal experiment with new hardware, software, communication devices, and electronic commerce, and how these things work and what their advantages and limitations are.

\subsection{Plan for future strategic alliances}

Murray and Mahon (1993) defines strategic alliance as a partnership of two or more corporations or business units to achieve strategically significant objectives that are mutually beneficial. Alliances between companies or business units have become a fact of life in modern business. On a practical level, Reeb (1999) claims that he can see firms sharing clients with other firms. He also can see industry CPAs outsourcing more to these networks, which will adapt themselves to changing market needs. He based his conclusion on:

- $\quad$ CPAs are changing - - CPAs will become more dependent on each other, fueling growth and service opportunities in the coming decade. Weinstein (1999) also believes that it would be difficult for the CPA firm keep its independence and still function alone.

- CPAs firms will share clients - - CPAs firms will share clients with other firms, creating informal cooperative networks. Hence, the future will benefit the CPA profession.

To be successful in this changing market, CPA firms of different sizes, Weinstein (1999) claims that CPA firms need to create alliances with other CPA firms. He believes that within the alliance, each profession could fill many different roles in the service continuum. He also suggests that alliance would need to be structured so that the generalists and specialists worked closely together in the best interest of both their clients and their firms.

5.10 Encourage ethical behavior in CPA firms

Sinclair (1993) attests that effective leaders emphasize ethical practices within their organizations. To the extent that employees and managers share a common set of ethical principles, there is a strong likelihood that ethical practices will be rewarding. For example, top executives of the pharmaceutical firm of Johnson and Johnson claim that one of the major sources for their success is their firm's culture, which emphasizes ethical conduct, even across international boundaries.

According to Keogh (1988) codes of ethics specify how an organization expects its employees to behave while on the job. Developing codes of ethics can be a useful way to promote ethical behavior. Kohut and Corriher (1994) notice that ethical codes are currently used by about half of American business corporations. A according to a 
report by Business Roundtable (an association of CEOs from 200 major U.S. corporations), the importance of a code of ethics is that it: (a) clarifies the company's expectations of employee conduct in various situations, and (b) makes clear that the company expects its people to recognize the ethical dimensions in its actions.

AICPA (1994) has developed its code of professional conduct. These principles express the profession's recognition of its responsibilities to the public, to clients, and to colleagues. They guide members in the performance of their professional responsibilities and express the basic tenets of ethical and professional conduct. The Principles call for commitment to honorable behavior, even at the sacrifice of personal advantage.

- $\quad$ Responsibilities - - In carrying out their responsibilities as professionals, members should exercise sensitive professional and moral judgments in all their activities.

- Public Interest - - Members should accept the obligation to act in a way that will serve the public interest, honor the public trust, and demonstrate commitment to professionalism.

- $\quad$ Public confidence - - To maintain and broaden public confidence, members should perform all professional responsibilities with the highest sense of integrity.

- $\quad$ Objectivity and Independence - - The CPA should maintain objectivity and be free of conflict of interest in discharging professional responsibilities. A CPA in public practice should be independent in fact and appearance when providing auditing and other attestation services.

- $\quad$ Due care - - The CPA should observe the profession's technical and ethical standards, strive continually to improve competence and the quality of services, and discharge professional responsibility to the best of his/her ability.

- $\quad$ Scope and Nature of Services - - The CPA in public practice should observe the Principles of the Code of Professional Conduct in determining the scope and nature of services to be provided.

\section{Conclusions}

A reading of contemporary accountants from the turn and the middle of the past century reveals how well the profession reflected the most dynamic activity of the period (Dennis, 2000). However, there is little doubt about the fact that CPA firms are changing (Reeb, 1999). Information technology is transforming the way data are created, transmitted, accessed and interpreted, making possible measurements and reporting. The greatest opportunity for growth of the CPA profession lies in new assurance services (Elliot and Pallais, 1997a).

It is often said that timing is everything. The future for CPAs will not be as what is used to be, but there will be many opportunities for expanding services and building on the profession (Siegel et al., 1997). Now is the time for the accounting profession to deal with the challenges it faces and to take a step into the future. CPAs must articulate a sharply defined view of their enhanced services and the body of knowledge that qualify them to offer those services for the sake of the public, future professionals and their educators (Pethley and Fremgen, 1999).

Reeb (1999) confirms that CPA firms will be dependent on each other, fueling growth and service opportunities in the coming decade. Future changes will evoke a unique spirit of cooperation through alliances. As specialties emerge, firms will have to choose the field they want to serve. He predicts a number of broad specialties for most alliances such as accounting, planning, human resources, marketing, technology, efficiency, and profitability will be core areas. Weinstein (1999) suggests that if CPA firms want to be successful, they have to find alliances with their counterparts.

\section{References}

1. AICPA, 1997. The special committee on assurance services. New York, NY: AICPA.

2. AICPA, 1994. Code of professional conduct as amended, New York: AICPA.

3. Carlozzi, C. 1998a. Learning for the future. Journal of Accountancy, July 186:42-44.

4. $\quad$ Carlozzi, C. 1998b. Mapping the road ahead. Journal of Accountancy, September 186: 62-64.

5. Dennis, A. 2000. No one stands still in public accounting: The CPA firm in 1900, 1950, and 2000. Journal 
of Accountancy, June 188: 67-79.

6. Elliot, K. E. 2000. Who are we as a profession--and what must we become? Journal of Accountancy, February 188: 81-85.

7. Elliott, R.K., and Pallais, D. M. 1997a. Are you ready for new assurance services? Journal of Accountancy, June 183: 47-51.

8. Elliott, R.K., and Pallais, D. M. 1997b. Build on your firm's strength. Journal of Accountancy, August 184: 53-58.

9. Felming, P. D. 1999. Steering a course for the future. Journal of Accountancy, November, 188: 64-71.

10. Golen, S. 1999. Communication with clients. Journal of Accountancy, November 186: 55-67.

11. Hunger, J. D., and Wheelen, T. L. 2000. Strategic management. New York, NY: Addison-Wesley.

12. International Federation of Accountants. 1995. Information technology in accounting curriculum-Guideline \# 1.

13. Issues in Accounting Education .1990. Objectives of Education for Accountants: Position Statement Number One. Accounting Education Change Commission, fall.

14. Keogh, J.1988. A Prime business asset. New York, NY: The Business Round Table.

15. Kohut, G.E, and Corriher, S. E. 994. The relationship of age, gender, experience and awareness of written ethics policies to business decision making. SAM Advancement Management Journal, winter 65:36-40.

16. Murray, E.A., and Mahon, J. F. 1993. Strategic alliances: Gateway to the new Europe. Long Range Planning. August 25: 103.

17. Porter, M. 1980. Competitive strategy: Techniques for analyzing industries and competitors. New York: NY, The Free Press.

18. Pethley, L. S., and Fremgen, R. I. 1999. What is in a name change? Journal of Accountancy, August 190:71-74.

19. Reeb, W. 1999. Future alliances. Journal of Accountancy, May 187: 27-30.

20. Roberto, K. A., and Yardley, J. A. 1999. Helping clients grow old gracefully. Journal of Accountancy, April 187: 43-47.

21. Sauser, L.D. 2000. The CPA profession: Respondin to a changing environment. SAM Advancement Management Journal, 12: 36-40.

22. Siegel, G. S., Kulesza, C.S., and Sorensen, J.E. 1997. Are you ready for the new accounting? Journal of Accountancy, August 184: 42-46.

23. Sinclair, A. 1993. Approaches to organizational culture and ethics. Journal of Business Ethics. 12: 63- 73.

24. Stark, J. S. 1995. Intentional learning: A Process for learning to learn in the accounting curriculum. Accounting Education Change Commission.

25. Tichy, N., and Charan, R. (1989). Speed, simplicity, self-confidence: An interview with Tack Welch. Harvard Business Review, 57: 113.

26. Weinstein, S. 1999. SOLO, but not alone. Journal of Accountancy, April 187: 35-38.

27. Zarowin, S. 1997, Apri. Finance's future: Challenge or threat. Journal of Accountancy, April 183: 38-42. 